\title{
Interventions to reduce suicides at suicide hotspots: a systematic review
}

\author{
Georgina R Cox ${ }^{1}$, Christabel Owens², Jo Robinson ${ }^{1}$, Angela Nicholas ${ }^{3}$, Anne Lockley ${ }^{3}$, Michelle Williamson ${ }^{3}$,
} Yee Tak Derek Cheung ${ }^{3}$ and Jane Pirkis ${ }^{3 *}$

\begin{abstract}
Background: 'Suicide hotspots' include tall structures (for example, bridges and cliffs), railway tracks, and isolated locations (for example, rural car parks) which offer direct means for suicide or seclusion that prevents intervention.

Methods: We searched Medline for studies that could inform the following question: 'What interventions are available to reduce suicides at hotspots, and are they effective?'

Results: There are four main approaches: (a) restricting access to means (through installation of physical barriers); (b) encouraging help-seeking (by placement of signs and telephones); (c) increasing the likelihood of intervention by a third party (through surveillance and staff training); and (d) encouraging responsible media reporting of suicide (through guidelines for journalists). There is relatively strong evidence that reducing access to means can avert suicides at hotspots without substitution effects. The evidence is weaker for the other approaches, although they show promise.
\end{abstract}

Conclusions: More well-designed intervention studies are needed to strengthen this evidence base.

Keywords: Suicide hotspots, Suicide prevention, Intervention

\section{Background}

A 'suicide hotspot' is a specific, accessible and usually public site which is frequently used as a location for suicide and gains a reputation as such [1]. The most common types of suicide hotspot are bridges, tall buildings and cliffs [2-5], railway tracks [6,7], and rural or secluded locations [8]. The suicide methods typically used at these sites, such as jumping from a height, jumping or lying in front of a train and inhalation of car exhaust have a high probability of being lethal [9]. Suicides at hotspots can have a distressing impact on those who witness the event, find the deceased or are involved in some other way $[10,11]$. They often receive high profile media coverage [12], which may increase the risk of 'suicide contagion'. There is no agreement on the number of suicides that is required to identify a site as a 'suicide hotspot'. However, more than one suicide at a particular location suggests that the site has appeal for suicidal

\footnotetext{
* Correspondence: j.pirkis@unimelb.edu.au

${ }^{3}$ Centre for Health Policy, Programs and Economics, Melbourne School of Population and Global Health, University of Melbourne, Melbourne, Australia Full list of author information is available at the end of the article
}

individuals and provides means or opportunity for suicide, and may therefore warrant intervention [13].

Various interventions have been implemented to reduce the risk of suicide at suicide hotspots. The current review examines the evidence for the effectiveness of these interventions. Specifically, it addresses the following research question: 'What interventions are available to reduce suicides at hotspots, and are they effective?'

\section{Methods}

Our review was conducted in accordance with the Preferred Reporting Items for Systematic Reviews and Meta-Analyses (PRISMA) Statement [14] (see Figure 1 and Table 1).

\section{Search strategy}

We searched Medline from its inception to April 2012 using the following search string, with words mapped onto MeSH headings: (suicid* OR hotspot) AND (cliff OR building OR high-rise OR multi-storey OR viaduct OR rail OR metro OR subway OR river OR lake OR sea OR public* OR secluded OR remote OR woods OR

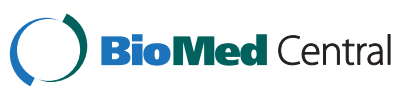




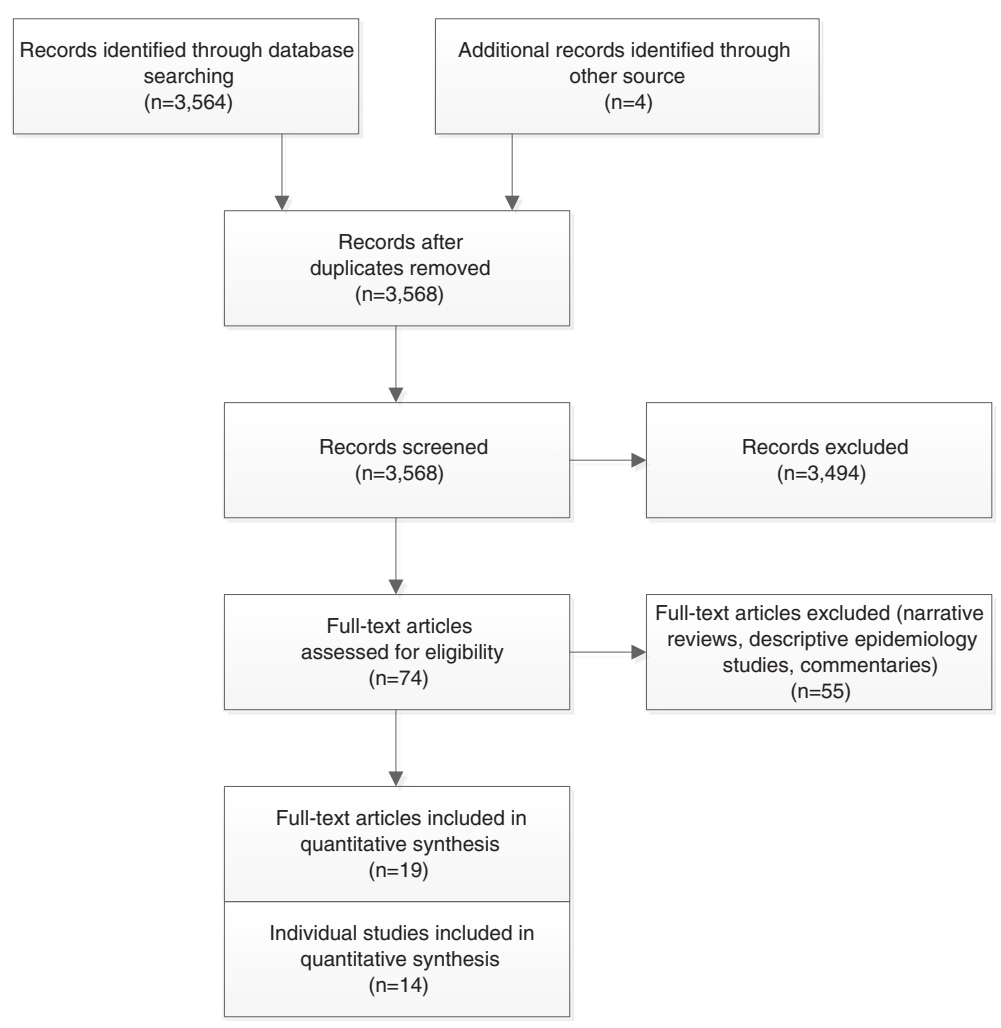

Figure 1 PRISMA flow diagram.

forest OR rural OR magnet OR location OR secluded OR bridge OR skyscraper OR car park OR underground OR road OR motorway OR highway OR reservoir OR coast OR jump* OR leap* OR fall OR height OR lie OR lying OR moving object OR carbon monoxide OR car exhaust OR hang* OR firearm OR gun* OR burn* OR drown* OR fenc* OR barrier* OR parapet OR net* OR pit* OR sign" OR poster* OR helpline* OR surveillance* OR CCTV OR patrol* OR media OR reporting OR television OR radio. Reference lists of key review papers and included studies were also searched. We sought only English-language publications.

\section{Study inclusion criteria}

We gave careful consideration to the kinds of studies that we would include in the review. Hotspot interventions are generally offered as universal preventive strategies, rather than as preventive strategies targeted at individuals. This means that evaluations usually draw on aggregate or ecological data on completed or attempted suicide, rather than individual-level data. It is practically and ethically difficult to mount cluster randomised controlled trials (cRCTs, regarded as Level I evidence) in this area. Suicide is an emotive issue and suicide hotspots generate considerable community concern, which means that randomly selecting some sites to receive the intervention is generally not feasible. Ecological studies with quasi-experimental designs (non-randomised studies with before-and-after designs and comparison sites, regarded as Level II evidence), are the next best solution, but comparable sites are not always available (for example, where one bridge is a recognised hotspot and nearby bridges do not present the same problem). This means that ecological studies with before-and-after designs and no comparison sites (regarded as Level III evidence) are often the most acceptable and appropriate option in the circumstances.

We included studies in the review if they described an intervention relating to a known suicide hotspot, evaluated it using at least a before-and-after design with no comparison (but preferably a stronger design), and used suicides as the outcome of interest (with or without other outcomes, such as suicide attempts). Studies which only measured suicides after an intervention was put in place and/or only considered outcomes other than suicides (such as calls to a crisis telephone service) were excluded.

\section{Data extraction}

The following data were extracted for each study:

- Author(s) and date of publication;

- Setting; 
Table 1 PRISMA checklist

SECTION/TOPIC \# CHECKLIST ITEM

\begin{tabular}{|c|c|c|c|}
\hline \multicolumn{4}{|l|}{ TITLE } \\
\hline Title & 1 & Identify the report as a systematic review, meta-analysis, or both. & 0 \\
\hline \multicolumn{4}{|l|}{ ABSTRACT } \\
\hline Structured summary & 2 & $\begin{array}{l}\text { Provide a structured summary including, as applicable: background; objectives; data sources; study } \\
\text { eligibility criteria, participants, and interventions; study appraisal and synthesis methods; results; } \\
\text { limitations; conclusions and implications of key findings; systematic review registration number. }\end{array}$ & 1 \\
\hline \multicolumn{4}{|l|}{ INTRODUCTION } \\
\hline Rationale & 3 & Describe the rationale for the review in the context of what is already known. & 1 \\
\hline Objectives & 4 & $\begin{array}{l}\text { Provide an explicit statement of questions being addressed with reference to participants, } \\
\text { interventions, comparisons, outcomes, and study design (PICOS). }\end{array}$ & 1 \\
\hline \multicolumn{4}{|l|}{ METHODS } \\
\hline $\begin{array}{l}\text { Protocol and } \\
\text { registration }\end{array}$ & 5 & $\begin{array}{l}\text { Indicate if a review protocol exists, if and where it can be accessed (e.g., Web address), and, if } \\
\text { available, provide registration information including registration number. }\end{array}$ & N/A \\
\hline Eligibility criteria & 6 & $\begin{array}{l}\text { Specify study characteristics (e.g., PICOS, length of follow-up) and report characteristics (e.g., years } \\
\text { considered, language, publication status) used as criteria for eligibility, giving rationale. }\end{array}$ & 2,4 \\
\hline Information sources & 7 & $\begin{array}{l}\text { Describe all information sources (e.g., databases with dates of coverage, contact with study authors to } \\
\text { identify additional studies) in the search and date last searched. }\end{array}$ & 1 \\
\hline Search & 8 & $\begin{array}{l}\text { Present full electronic search strategy for at least one database, including any limits used, such that it } \\
\text { could be repeated. }\end{array}$ & $1-2$ \\
\hline Study selection & 9 & $\begin{array}{l}\text { State the process for selecting studies (i.e., screening, eligibility, included in systematic review, and, if } \\
\text { applicable, included in the meta-analysis). }\end{array}$ & 2 \\
\hline $\begin{array}{l}\text { Data collection } \\
\text { process }\end{array}$ & 10 & $\begin{array}{l}\text { Describe method of data extraction from reports (e.g., piloted forms, independently, in duplicate) and } \\
\text { any processes for obtaining and confirming data from investigators. }\end{array}$ & 2,4 \\
\hline Data items & 11 & $\begin{array}{l}\text { List and define all variables for which data were sought (e.g., PICOS, funding sources) and any } \\
\text { assumptions and simplifications made. }\end{array}$ & 2,4 \\
\hline $\begin{array}{l}\text { Risk of bias in } \\
\text { individual studies }\end{array}$ & 12 & $\begin{array}{l}\text { Describe methods used for assessing risk of bias of individual studies (including specification of } \\
\text { whether this was done at the study or outcome level), and how this information is to be used in any } \\
\text { data synthesis. }\end{array}$ & 11 \\
\hline Summary measures & 13 & State the principal summary measures (e.g., risk ratio, difference in means). & 4 \\
\hline Synthesis of results & 14 & $\begin{array}{l}\text { Describe the methods of handling data and combining results of studies, if done, including measures } \\
\text { of consistency }\left(e . g ., I^{2}\right) \text { for each meta-analysis. }\end{array}$ & 4 \\
\hline $\begin{array}{l}\text { Risk of bias across } \\
\text { studies }\end{array}$ & 15 & $\begin{array}{l}\text { Specify any assessment of risk of bias that may affect the cumulative evidence (e.g., publication bias, } \\
\text { selective reporting within studies). }\end{array}$ & 11 \\
\hline Additional analyses & 16 & $\begin{array}{l}\text { Describe methods of additional analyses (e.g., sensitivity or subgroup analyses, meta-regression), if } \\
\text { done, indicating which were pre-specified. }\end{array}$ & N/A \\
\hline \multicolumn{4}{|l|}{ RESULTS } \\
\hline Study selection & 17 & $\begin{array}{l}\text { Give numbers of studies screened, assessed for eligibility, and included in the review, with reasons for } \\
\text { exclusions at each stage, ideally with a flow diagram. }\end{array}$ & 2 \\
\hline Study characteristics & 18 & $\begin{array}{l}\text { For each study, present characteristics for which data were extracted (e.g., study size, PICOS, follow-up } \\
\text { period) and provide the citations. }\end{array}$ & $5-8$ \\
\hline $\begin{array}{l}\text { Risk of bias within } \\
\text { studies }\end{array}$ & 19 & $\begin{array}{l}\text { Present data on risk of bias of each study and, if available, any outcome level assessment (see item } \\
\text { 12). }\end{array}$ & N/A \\
\hline $\begin{array}{l}\text { Results of individual } \\
\text { studies }\end{array}$ & 20 & $\begin{array}{l}\text { For all outcomes considered (benefits or harms), present, for each study: (a) simple summary data for } \\
\text { each intervention group (b) effect estimates and confidence intervals, ideally with a forest plot. }\end{array}$ & $5-8$ \\
\hline Synthesis of results & 21 & $\begin{array}{l}\text { Present results of each meta-analysis done, including confidence intervals and measures of } \\
\text { consistency. }\end{array}$ & N/A \\
\hline $\begin{array}{l}\text { Risk of bias across } \\
\text { studies }\end{array}$ & 22 & Present results of any assessment of risk of bias across studies (see Item 15). & N/A \\
\hline Additional analysis & 23 & $\begin{array}{l}\text { Give results of additional analyses, if done (e.g., sensitivity or subgroup analyses, meta-regression [see } \\
\text { Item 16]). }\end{array}$ & N/A \\
\hline \multicolumn{4}{|l|}{ DISCUSSION } \\
\hline Summary of evidence & 24 & $\begin{array}{l}\text { Summarize the main findings including the strength of evidence for each main outcome; consider } \\
\text { their relevance to key groups (e.g., healthcare providers, users, and policy makers). }\end{array}$ & 4,9 \\
\hline
\end{tabular}


Table 1 PRISMA checklist (Continued)

\begin{tabular}{lcl}
\hline Limitations & $25 \begin{array}{l}\text { Discuss limitations at study and outcome level (e.g., risk of bias), and at review-level (e.g., incomplete } \\
\text { retrieval of identified research, reporting bias). }\end{array}$ \\
\hline Conclusions & $26 \begin{array}{l}\text { Provide a general interpretation of the results in the context of other evidence, and implications for } \\
\text { future research. }\end{array}$ \\
\hline FUNDING & $27 \begin{array}{l}\text { Describe sources of funding for the systematic review and other support (e.g., supply of data); role of } \\
\text { funders for the systematic review. }\end{array}$ \\
\hline Funding & 11 \\
\hline
\end{tabular}

- General approach(es);

- Specific intervention(s);

- Study design and observation period; and

- Findings.

With respect to the findings, data were examined on changes in the number or rate of suicides at the hotspot site and at comparison sites where these were available. Consideration was also given to whether there was any evidence of substitution, either in the form of site substitution (reduction in suicides at the hotspot being accompanied by increases at other nearby sites) or method substitution (reduction in use of one method being accompanied by increases in others).

\section{Results}

Nineteen papers describing 14 studies at 13 locations worldwide met our inclusion criteria [15-33], and are summarised in Table 2. There were several instances where the same group of authors used the same core data in more than one paper, augmenting it with data from other sources or with follow-up data [15-20,26,32]. In these cases, we took the conservative approach of regarding the different papers as relating to the same study to avoid double-counting of any observed impacts, thereby circumventing the possibility of multiple publication bias. There was one instance in which the same data were examined independently by separate investigators to determine the impact of the same intervention at the same site [24,27]. These were regarded as separate studies, but their findings are discussed together, again to avoid artificially inflating the collective magnitude of any impact.

The interventions studied fall into four broad categories representing different approaches to suicide prevention. The most commonly-investigated of these is restricting access to means (for example, by installing barriers at a jumping site). The second approach involves encouraging help-seeking (for example, via signs and telephone crisis lines). The third intervention involves increasing the likelihood of intervention by a third party (for example, offering training for staff working at or near suicide hotspots and/or surveillance methods). The final approach is the provision of guidance on responsible reporting of suicide to media professionals, in order to minimise the risk of 'suicide contagion' at hotspots. Most of the studies consider a single intervention, but some consider several together.

\section{Restricting access to means}

Nine studies have examined the effectiveness of restricting access to lethal means by installing physical barriers at sites that are used for jumping from a height or jumping in front of a train. All of these studies suggest that suicides reduce once means restriction measures are put in place [15-18,22-24,27-31], or rise when they are removed $[15,16]$.

Pelletier [28], Reisch and Michel [29] and Sinyor and Levitt [30] observed no further suicides after barriers were installed on the Memorial Bridge in Augusta, Maine (United States), Muenster Terrace in Bern (Switzerland) and the Bloor Street Viaduct in Toronto (Canada), respectively. Isaac and Bennett [22] and Skegg and Herbison [31] reported the same 'reduction to zero' finding when access was blocked to Beachy Head in Sussex (United Kingdom) and Lawyers Head Cliff in Dunedin (New Zealand). Bennewith and colleagues $[17,18]$ also reported substantial decreases in the number of suicides (though not a complete elimination of them) following the erection of fencing on the Clifton Suspension Bridge in Bristol (United Kingdom). The fencing was accompanied by an expansion of the role of bridge staff to include monitoring of incidents, and the installation of CCTV cameras (see below). Lester [24] and O'Carroll and Silverman [27] reported similar findings to those of Bennewith and colleagues $[17,18]$ when they independently examined data on suicides before and after modifications to the Ellington Bridge in Washington, DC (United States). Law et al. also noted a significant decrease in suicides following the introduction of platform screen doors on the Hong Kong underground railway system (Hong Kong) [23]. Conversely, when barriers on the Grafton Bridge in Auckland (New Zealand) were removed for aesthetic reasons, Beautrais and colleagues observed an increase in suicides $[15,16]$. Replacement of the original barriers by new ones with an improved design was followed by a decrease in suicides $[15,16]$.

Eight of the above studies made some attempt to examine whether the reductions in suicide at the sites in 


\section{Table 2 Study characteristics and results}

\begin{tabular}{|c|c|c|c|c|c|c|}
\hline Author(s) and date & $\begin{array}{l}\text { Study } \\
\text { number }\end{array}$ & Setting & $\begin{array}{l}\text { General } \\
\text { approach(es) }\end{array}$ & Specific intervention(s) & $\begin{array}{l}\text { Study design and } \\
\text { observation period }\end{array}$ & Findings \\
\hline \multirow[t]{5}{*}{$\begin{array}{l}\text { Beautrais (2001) [15]; } \\
\text { Beautrais et al. (2009) [16] }\end{array}$} & \multirow[t]{5}{*}{1} & \multirow[t]{5}{*}{$\begin{array}{l}\text { Grafton Bridge, Auckland, New } \\
\text { Zealand. }\end{array}$} & \multirow[t]{5}{*}{$\begin{array}{l}\text { - Restricting } \\
\text { access to lethal } \\
\text { means }\end{array}$} & \multirow{5}{*}{$\begin{array}{l}\text { Metal screens fixed above } \\
\text { concrete parapets for purposes of } \\
\text { suicide prevention, removed in } \\
1996 \text {. Reinstallation of a barrier in } \\
2003 \text { with an improved curved } \\
\text { glass design. }\end{array}$} & $\begin{array}{l}\text { A-B-A (reversal) study assessing } \\
\text { number and rates of suicides in } \\
\text { three periods: }\end{array}$ & \multirow{3}{*}{$\begin{array}{l}\text { - Five suicides from the bridge } \\
\text { during period in which original } \\
\text { barriers were in place (1.0 per } \\
\text { year). This rose to } 19 \text { in period } \\
\text { when original barriers were } \\
\text { removed ( } 3.2 \text { per year). No } \\
\text { suicides occurred after the } \\
\text { installation of the new barrier. }\end{array}$} \\
\hline & & & & & $\begin{array}{l}\text { - 1991-1995 (5-year period in } \\
\text { which original barriers were in } \\
\text { place); }\end{array}$ & \\
\hline & & & & & \multirow{2}{*}{$\begin{array}{l}\text { - } 1997-2002 \text { ( } 5 \text { year period in } \\
\text { which no barriers were in } \\
\text { place); and }\end{array}$} & \\
\hline & & & & & & \multirow[t]{2}{*}{$\begin{array}{l}\text { - No change in overall number of } \\
\text { suicides by jumping in Auckland. }\end{array}$} \\
\hline & & & & & $\begin{array}{l}\text { - 2003-2006 ( } 5 \text { year period in } \\
\text { which new barriers were in } \\
\text { place). }\end{array}$ & \\
\hline \multirow[t]{8}{*}{$\begin{array}{l}\text { Bennewith, Nowers and } \\
\text { Gunnell (2007) [17]; } \\
\text { Bennewith, Nowers and } \\
\text { Gunnell (2011) [18] }\end{array}$} & \multirow[t]{8}{*}{2} & \multirow[t]{8}{*}{$\begin{array}{l}\text { Clifton Suspension Bridge, } \\
\text { Bristol, United Kingdom. }\end{array}$} & $\begin{array}{l}\text { - Restricting } \\
\text { access to lethal } \\
\text { means }\end{array}$ & $\begin{array}{l}\text { Two metre high wire fencing } \\
\text { installed on main span in } 1998 .\end{array}$ & $\begin{array}{l}\text { Before-and-after analysis } \\
\text { comparing number of suicides } \\
\text { in two periods: }\end{array}$ & $\begin{array}{l}\text { - Suicides dropped from } 8.2 \text { per } \\
\text { year in period prior to installation } \\
\text { of fencing to } 4.0 \text { per year in } \\
\text { period following it. }\end{array}$ \\
\hline & & & \multirow{7}{*}{$\begin{array}{l}\text { - Increasing the } \\
\text { likelihood of } \\
\text { intervention by a } \\
\text { third party }\end{array}$} & \multirow{7}{*}{$\begin{array}{l}\text { Role of bridge staff expanded to } \\
\text { include ensuring individuals' } \\
\text { safety and monitoring incidents. } \\
\text { CCTV cameras installed. }\end{array}$} & $\begin{array}{l}\text { - 1994-1998 (5-year pre- } \\
\text { intervention period); and }\end{array}$ & $\begin{array}{l}\text { period following it. } \\
\text { - } 90 \% \text { of suicides from the bridge }\end{array}$ \\
\hline & & & & & $\begin{array}{l}\text { - 1999-2003 (5-year post- } \\
\text { intervention period). }\end{array}$ & \multirow{2}{*}{$\begin{array}{l}\text { - } 90 \% \text { of suicides from the bridge } \\
\text { were by males but there was no } \\
\text { evidence of an increase in male } \\
\text { suicide by jumping from other } \\
\text { sites in Bristol following the } \\
\text { installation. }\end{array}$} \\
\hline & & & & & $\begin{array}{l}\text { Before-and-after analysis } \\
\text { comparing number of suicides } \\
\text { in two periods: }\end{array}$ & \\
\hline & & & & & $\begin{array}{l}\text { - 1996-1998 (3-year pre- } \\
\text { intervention period); and }\end{array}$ & \multirow{2}{*}{$\begin{array}{l}\text { - Number of incidents remained } \\
\text { stable ( } 39 \text { per year in pre- } \\
\text { installation period; } 43 \text { per year in } \\
\text { post-installation period). }\end{array}$} \\
\hline & & & & & \multirow{3}{*}{$\begin{array}{l}\text { - 1999-2005 (7-year post- } \\
\text { intervention period). } \\
\text { Interviews with } 10 \text { of } 13 \text { bridge } \\
\text { staff. }\end{array}$} & \\
\hline & & & & & & $\begin{array}{l}\text { - Bridge staff more likely to be } \\
\text { involved in incidents after the } \\
\text { installation of barriers. }\end{array}$ \\
\hline & & & & & & $\begin{array}{l}\text { - Majority of interviewed bridge } \\
\text { staff felt that the barriers had been } \\
\text { successful in preventing suicide. }\end{array}$ \\
\hline \multirow[t]{2}{*}{$\begin{array}{l}\text { Etzersdorfer and Sonneck } \\
\text { (1992) [19]; Sonneck, } \\
\text { Etzersdorfer and Nagel-Kuess } \\
\text { (1994) [32]; Etzersdorfer and } \\
\text { Sonneck (1998) [20]; } \\
\text { Niederkrotenthaler and } \\
\text { Sonneck (2007) [26] }\end{array}$} & \multirow[t]{2}{*}{3} & \multirow[t]{2}{*}{$\begin{array}{l}\text { Vienna underground railway } \\
\text { system, Vienna, Austria }\end{array}$} & \multirow[t]{2}{*}{$\begin{array}{l}\text { - Providing } \\
\text { guidance on } \\
\text { responsible media } \\
\text { reporting of } \\
\text { suicide }\end{array}$} & \multirow[t]{2}{*}{$\begin{array}{l}\text { Guidelines on media reporting of } \\
\text { suicides - with particular } \\
\text { reference to railway suicides - } \\
\text { developed and disseminated. }\end{array}$} & $\begin{array}{l}\text { Before-and-after analysis } \\
\text { comparing number of } \\
\text { completed and attempted } \\
\text { railway suicides in two periods: } \\
\text { - } 1 \text { Jan } 1980 \text { - } 30 \text { June } 1987 \\
\text { ( } 7.5 \text { year pre-intervention } \\
\text { period); and }\end{array}$ & \multirow{2}{*}{$\begin{array}{l}\text { - Suicidal acts on the underground } \\
\text { railway system rose dramatically in } \\
\text { the latter part of the pre- } \\
\text { intervention period (when } \\
\text { sensationalist reports of suicide } \\
\text { were common), peaking at nine } \\
\text { completed suicides and } 10 \\
\text { attempted suicides in the first half } \\
\text { of } 1987 \text {. Following the } \\
\text { introduction of the guidelines, } \\
\text { both completed and attempted }\end{array}$} \\
\hline & & & & & $\begin{array}{l}\cdot 1 \text { July } 1987-31 \text { Dec } 1996 \\
\text { (9.5 year post-intervention } \\
\text { period). }\end{array}$ & \\
\hline
\end{tabular}


Table 2 Study characteristics and results (Continued)

\begin{tabular}{|c|c|c|c|c|c|c|}
\hline & & & & & $\begin{array}{l}\text { Subsequent interrupted time } \\
\text { series analysis that examined } \\
\text { trends in overall suicides from } \\
1946 / 47 \text { to } 2004 / 05 \text { and trends } \\
\text { in railway suicides from 1982/ } \\
83 \text { to 2004/05. }\end{array}$ & $\begin{array}{l}\text { suicides dropped dramatically (to } \\
\text { two and one incidents, } \\
\text { respectively). This level was then } \\
\text { sustained for the remainder of the } \\
\text { observation period. } \\
\text { - Some evidence of nationwide } \\
\text { impact, with a reduction of } 81 \\
\text { overall suicides. }\end{array}$ \\
\hline \multirow[t]{3}{*}{ Isaac and Bennett (2005) [22] } & \multirow[t]{3}{*}{4} & \multirow[t]{3}{*}{$\begin{array}{l}\text { Beachy Head, Sussex, United } \\
\text { Kingdom }\end{array}$} & \multirow[t]{3}{*}{$\begin{array}{l}\text { - Restricting } \\
\text { access to lethal } \\
\text { means }\end{array}$} & \multirow[t]{3}{*}{$\begin{array}{l}\text { Road access blocked from Jan- } \\
\text { Jun } 2001 \text { due to foot and mouth } \\
\text { crisis }\end{array}$} & $\begin{array}{l}\text { Before-and-after analysis } \\
\text { comparing number of suicides } \\
\text { in two periods: }\end{array}$ & \multirow{3}{*}{$\begin{array}{l}\text { - Suicides had risen to a high in } \\
\text { the pre-intervention period ( } 85 \% \\
\text { higher than in 1965-1979) but } \\
\text { reduced to zero once road access } \\
\text { was blocked. }\end{array}$} \\
\hline & & & & & $\begin{array}{l}\text { - 1987-2000 inclusive (14-year } \\
\text { pre-intervention period); and }\end{array}$ & \\
\hline & & & & & $\begin{array}{l}\text { - Jan-Jun } 2001 \text { (6-month post- } \\
\text { intervention period). }\end{array}$ & \\
\hline \multirow[t]{5}{*}{ Law et al. (2009) [23] } & \multirow[t]{5}{*}{5} & \multirow{5}{*}{$\begin{array}{l}\text { Hong Kong underground } \\
\text { railway system, Hong Kong. } \\
\text { This system is operated by the } \\
\text { Mass Transit Railway (MTR) } \\
\text { Corporation and the Kowloon- } \\
\text { Canton Railway (KCR) } \\
\text { Corporation. }\end{array}$} & \multirow{5}{*}{$\begin{array}{l}\text { - Restricting } \\
\text { access to lethal } \\
\text { means }\end{array}$} & \multirow{5}{*}{$\begin{array}{l}\text { Platform Screen Doors (PSDs) } \\
\text { installed on } 71 \text { platforms in } 30 \\
\text { MTR underground stations on } \\
\text { three prominent transit lines. } \\
\text { Work began in } 2002 \text { and ended } \\
\text { in } 2005 \text {, but most of the busiest } \\
\text { station platforms were sealed in } \\
\text { the first year. }\end{array}$} & $\begin{array}{l}\text { Before-and-after analysis } \\
\text { comparing number of suicides } \\
\text { in two periods. }\end{array}$ & \multirow{3}{*}{$\begin{array}{l}\text { - Significant decrease in the } \\
\text { number of suicides on the Hong } \\
\text { Kong underground railway system } \\
\text { from } 51 \text { ( } 10.2 \text { per year) in the pre- } \\
\text { installation period to } 22 \text { ( } 4.4 \text { per } \\
\text { year) in the post-installation } \\
\text { period. }\end{array}$} \\
\hline & & & & & $\begin{array}{l}\text {-1997-2001 (5-year pre- } \\
\text { intervention period); and }\end{array}$ & \\
\hline & & & & & \multirow{2}{*}{$\begin{array}{l}\text { - 2003-2007 (5-year post- } \\
\text { intervention period). }\end{array}$} & \\
\hline & & & & & & \multirow[b]{2}{*}{$\begin{array}{l}\text { - No evidence for displacement to } \\
\text { other rail platforms; the number of } \\
\text { suicides at MTR stations dropped } \\
\text { from } 38 \text { to seven, whereas the } \\
\text { number at KCR stations remained } \\
\text { fairly stable ( } 13 \text { in the pre- } \\
\text { installation period and } 15 \text { in the } \\
\text { post-installation period). }\end{array}$} \\
\hline & & & & & $\begin{array}{l}\text { Incorporated quasi- } \\
\text { experimental design element } \\
\text { which considered numbers of } \\
\text { suicides over time at stations } \\
\text { with and without PSDs. }\end{array}$ & \\
\hline \multirow[t]{6}{*}{ King and Frost (2005) [21] } & \multirow[t]{6}{*}{6} & \multirow[t]{6}{*}{$\begin{array}{l}\text { New Forest, Hampshire, United } \\
\text { Kingdom }\end{array}$} & \multirow[t]{6}{*}{$\begin{array}{l}\text { • Encouraging } \\
\text { help-seeking }\end{array}$} & \multirow[t]{6}{*}{$\begin{array}{l}\text { Signs displaying Samaritans' } \\
\text { national telephone number } \\
\text { placed in } 26 \text { car parks in } 1998 .\end{array}$} & $\begin{array}{l}\text { Before-and-after analysis } \\
\text { comparing number of suicides } \\
\text { in two periods: }\end{array}$ & \multirow[t]{2}{*}{$\begin{array}{l}\text { - Car park suicides dropped from } \\
10.0 \text { per year in period prior to } \\
\text { installation of signs to } 3.3 \text { per year } \\
\text { in the period following it. }\end{array}$} \\
\hline & & & & & \multirow{2}{*}{$\begin{array}{l}\text { - } 1 \text { Oct } 1988 \text { - } 30 \text { Sept } 1998 \\
\text { (10-year pre-intervention } \\
\text { period); and }\end{array}$} & \\
\hline & & & & & & \multirow{2}{*}{$\begin{array}{l}\text { - Average annual total number of } \\
\text { suicides in the district also } \\
\text { decreased. }\end{array}$} \\
\hline & & & & & \multirow{2}{*}{$\begin{array}{l}\text { - } 1 \text { Oct } 1998 \text { - } 30 \text { Sept } 2001 \text { (3- } \\
\text { year post-intervention period). }\end{array}$} & \\
\hline & & & & & & \multirow{2}{*}{$\begin{array}{l}\text { - No changes were found in } \\
\text { comparable forest districts. }\end{array}$} \\
\hline & & & & & $\begin{array}{l}\text { Incorporated quasi- } \\
\text { experimental design element } \\
\text { which considered numbers of } \\
\text { suicides in same periods in } \\
\text { comparable forest districts. }\end{array}$ & \\
\hline
\end{tabular}


Table 2 Study characteristics and results (Continued)

\begin{tabular}{|c|c|c|c|c|c|c|}
\hline \multirow[t]{4}{*}{$\begin{array}{l}\text { Lester (1993)[24]; O'Carroll } \\
\text { and Silverman (1994) [27] }\end{array}$} & \multirow[t]{4}{*}{7,8} & \multirow[t]{4}{*}{$\begin{array}{l}\text { Ellington Bridge, Washington } \\
\text { DC, United States }\end{array}$} & \multirow[t]{4}{*}{$\begin{array}{l}\text { - Restricting } \\
\text { access to lethal } \\
\text { means }\end{array}$} & \multirow[t]{4}{*}{ Eight foot fence installed in 1986.} & $\begin{array}{l}\text { Before-and-after analysis } \\
\text { comparing number of suicides } \\
\text { in two periods: }\end{array}$ & \multirow[t]{2}{*}{$\begin{array}{l}\text { - Suicides dropped from } 3.7 \text { per } \\
\text { year in period prior to installation } \\
\text { of fencing to } 0.2 \text { per year in } \\
\text { period following it. }\end{array}$} \\
\hline & & & & & $\begin{array}{l}\text { - 1979-1985 (7-year pre- } \\
\text { intervention period); and }\end{array}$ & \\
\hline & & & & & \multirow[t]{2}{*}{$\begin{array}{l}\text { - 1986-1990 (5-year post- } \\
\text { intervention period). }\end{array}$} & $\begin{array}{l}\text { - Suicides from nearby Taft Bridge } \\
\text { remained relatively stable ( } 1.7 \text { in } \\
\text { pre-installation period; } 2.0 \text { in post- } \\
\text { installation period). }\end{array}$ \\
\hline & & & & & & $\begin{array}{l}\text { - Overall mean number of suicides } \\
\text { in Washington DC was } 76.4 \text { in the } \\
\text { pre-installation period and } 71.6 \text { in } \\
\text { the post-installation period. }\end{array}$ \\
\hline \multirow[t]{3}{*}{ Lester (2005) [25] } & \multirow[t]{3}{*}{9} & \multirow[t]{3}{*}{$\begin{array}{l}\text { Sunshine Skyway Bridge, St } \\
\text { Petersburg, Florida, United } \\
\text { States }\end{array}$} & \multirow[t]{2}{*}{$\begin{array}{l}\text { - Encouraging } \\
\text { help-seeking }\end{array}$} & \multirow[t]{3}{*}{$\begin{array}{l}\text { Crisis emergency telephones } \\
\text { installed in } 1999 \text { and a police } \\
\text { presence on the bridge } \\
\text { established at the same time. }\end{array}$} & $\begin{array}{l}\text { Before-and-after analysis } \\
\text { comparing number of suicides } \\
\text { in two periods: }\end{array}$ & \multirow[t]{3}{*}{$\begin{array}{l}\text { - Suicides dropped from } 25 \text { in pre- } \\
\text { intervention period ( } 8.3 \text { per year) } \\
\text { to } 19 \text { in post-intervention period } \\
\text { ( } 6.3 \text { per year). }\end{array}$} \\
\hline & & & & & $\begin{array}{l}\text { - 1996-1998 (3-year pre- } \\
\text { intervention period); and }\end{array}$ & \\
\hline & & & $\begin{array}{l}\text { - Increasing the } \\
\text { likelihood of } \\
\text { intervention by a } \\
\text { third party }\end{array}$ & & $\begin{array}{l}\text { - 2000-2002 (3-year post- } \\
\text { intervention period). }\end{array}$ & \\
\hline \multirow[t]{4}{*}{ Pelletier (2007) [28] } & \multirow[t]{4}{*}{10} & \multirow[t]{4}{*}{$\begin{array}{l}\text { Memorial Bridge, Augusta, } \\
\text { Maine, United States. }\end{array}$} & \multirow[t]{4}{*}{$\begin{array}{l}\text { - Restricting } \\
\text { access to lethal } \\
\text { means }\end{array}$} & \multirow[t]{4}{*}{$\begin{array}{l}11 \text { foot high fence installed on } \\
\text { either side bridge in } 1983 .\end{array}$} & $\begin{array}{l}\text { Before-and-after analysis } \\
\text { comparing number of suicides } \\
\text { in two periods: }\end{array}$ & $\begin{array}{l}\text { - } 14 \text { suicides in period prior to } \\
\text { installation of fence; none in } \\
\text { period following installation. }\end{array}$ \\
\hline & & & & & $\begin{array}{l}\text { - } 1 \text { Apr } 1960 \text { - } 31 \text { May } 1983 \\
\text { (22-year pre-intervention } \\
\text { period); and }\end{array}$ & \multirow{2}{*}{$\begin{array}{l}\text { - Number of suicides by jumping } \\
\text { or drowning at sites in Augusta } \\
\text { other than the Memorial Bridge } \\
\text { remained unchanged (nine in } \\
\text { each period). }\end{array}$} \\
\hline & & & & & \multirow[t]{2}{*}{$\begin{array}{l}\text { - } 1 \text { Jun } 1983 \text { - } 31 \text { Jul } 2005 \text { (22- } \\
\text { year post-intervention period). }\end{array}$} & \\
\hline & & & & & & $\begin{array}{l}\text { - Overall suicide rate in Augusta } \\
\text { dropped by } 9.0 \% \text { (from } 26.0 / \\
100,000 \text { in pre-installation period } \\
\text { to } 23.8 \text { per } 100 / 000 \text { in post- } \\
\text { installation period). }\end{array}$ \\
\hline \multirow[t]{4}{*}{ Reisch and Michel (2005) [29] } & \multirow[t]{4}{*}{11} & \multirow[t]{4}{*}{$\begin{array}{l}\text { Muenster Terrace, Bern, } \\
\text { Switzerland. }\end{array}$} & \multirow[t]{4}{*}{$\begin{array}{l}\text { - Restricting } \\
\text { access to lethal } \\
\text { means }\end{array}$} & \multirow[t]{4}{*}{$\begin{array}{l}\text { Four metre wide wire mesh net, } \\
7 \text { metres below top of terrace } \\
\text { installed in } 1998 \text { following high } \\
\text { level of media attention. }\end{array}$} & \multirow{2}{*}{$\begin{array}{l}\text { Interrupted time series analysis } \\
\text { assessing expected and } \\
\text { observed numbers of suicides } \\
\text { in two periods: }\end{array}$} & $\begin{array}{l}\text { - No suicides from the terrace in } \\
\text { the period following installation of } \\
\text { safety net. }\end{array}$ \\
\hline & & & & & & \multirow{3}{*}{$\begin{array}{l}\text { - Overall decrease in suicides by } \\
\text { jumping from all sites in Bern ( } 95 \\
\text { expected; } 44 \text { observed). }\end{array}$} \\
\hline & & & & & $\begin{array}{l}\text { - 1995-1998 (4-year pre- } \\
\text { intervention period); and }\end{array}$ & \\
\hline & & & & & $\begin{array}{l}\text { - 1999-2002 (4-year post- } \\
\text { intervention period) }\end{array}$ & \\
\hline
\end{tabular}


Table 2 Study characteristics and results (Continued)

\begin{tabular}{|c|c|c|c|c|c|c|}
\hline \multirow[t]{3}{*}{ Sinyor and Levitt (2010) [30] } & \multirow[t]{3}{*}{12} & \multirow[t]{3}{*}{$\begin{array}{l}\text { Bloor Street Viaduct, Toronto, } \\
\text { Canada }\end{array}$} & \multirow[t]{3}{*}{$\begin{array}{l}\text { - Restricting } \\
\text { access to lethal } \\
\text { means }\end{array}$} & \multirow{3}{*}{$\begin{array}{l}\text { Five metre high barrier } \\
\text { constructed between April } 2002 \\
\text { and June } 2003 \text { comprising } \\
\text { closely-spaced steel rods } \\
\text { supported by an angled steel } \\
\text { frame. }\end{array}$} & $\begin{array}{l}\text { Before-and-after analysis } \\
\text { comparing number of suicides } \\
\text { in pre- and post-intervention } \\
\text { periods: }\end{array}$ & $\begin{array}{l}\text { - Annual numbers of suicide from } \\
\text { the viaduct dropped from } 9.3 \text { to } \\
0.0 \text { after the barrier was installed. }\end{array}$ \\
\hline & & & & & $\begin{array}{l}\text { - 1993-2001 (9-year pre- } \\
\text { intervention period); and }\end{array}$ & \multirow{2}{*}{$\begin{array}{l}\text { - No reduction in overall rates of } \\
\text { suicide by jumping due to } \\
\text { increase in suicides by this } \\
\text { method at other Toronto sites. }\end{array}$} \\
\hline & & & & & $\begin{array}{l}\text { - 2003-2007 (5-year post- } \\
\text { intervention period). }\end{array}$ & \\
\hline \multirow[t]{6}{*}{$\begin{array}{l}\text { Skegg and Herbison (2009) } \\
\text { [31] }\end{array}$} & \multirow[t]{6}{*}{13} & \multirow[t]{6}{*}{$\begin{array}{l}\text { Lawyers Head Cliff, Dunedin, } \\
\text { New Zealand }\end{array}$} & \multirow[t]{6}{*}{$\begin{array}{l}\text { - Restricting } \\
\text { access to lethal } \\
\text { means }\end{array}$} & \multirow[t]{6}{*}{$\begin{array}{l}\text { Road access blocked in } 2006 \text { due } \\
\text { to maintenance. }\end{array}$} & $\begin{array}{l}\text { Before-and-after analysis } \\
\text { comparing number of suicides } \\
\text { in two periods: }\end{array}$ & \multirow{2}{*}{$\begin{array}{l}\text { - } 14 \text { deaths in the } 10 \text {-year period } \\
\text { before closure ( } 11 \text { suicides, two } \\
\text { open verdicts and one accidental } \\
\text { death); none during } 2 \text {-year closure } \\
\text { period. }\end{array}$} \\
\hline & & & & & $\begin{array}{l}\text { - } 1 \text { Aug } 1996 \text { - } 31 \text { Jul } 2006 \text { (10- } \\
\text { year pre-intervention period); and }\end{array}$ & \\
\hline & & & & & $\begin{array}{l}\text { - } 1 \text { Aug } 2006 \text { - } 31 \text { Jul } 2008 \text { (2- } \\
\text { year post-intervention period). }\end{array}$ & \multirow{4}{*}{$\begin{array}{l}\text { - } 77 \text { police call outs for threatened } \\
\text { or attempted suicide in } 4 \text {-year } \\
\text { period before closure ( } 19.3 \text { per } \\
\text { year); } 19 \text { call-outs during closure } \\
\text { period ( } 9.8 \text { per year). }\end{array}$} \\
\hline & & & & & $\begin{array}{l}\text { Before-and-after analysis } \\
\text { comparing number of police } \\
\text { call-outs in two periods: }\end{array}$ & \\
\hline & & & & & $\begin{array}{l}\text { - } 1 \text { Aug } 2002 \text { - } 31 \text { Jul } 2006 \text { (4- } \\
\text { year pre-intervention period); } \\
\text { and }\end{array}$ & \\
\hline & & & & & $\begin{array}{l}\text { - } 1 \text { Aug } 2006 \text { - } 31 \text { Jul } 2008 \text { (2- } \\
\text { year post-intervention period). }\end{array}$ & \\
\hline \multirow[t]{6}{*}{ Wong et al. (2009) [33] } & \multirow[t]{6}{*}{14} & \multirow{6}{*}{$\begin{array}{l}\text { Cheung Chau, Hong Kong. } \\
\text { This is an island which } \\
\text { attracted visitors who rented } \\
\text { holiday flats in which they } \\
\text { took their own lives by } \\
\text { charcoal burning. }\end{array}$} & \multirow{6}{*}{$\begin{array}{l}\text { - Encouraging } \\
\text { help-seeking } \\
\text { - Increasing the } \\
\text { likelihood of } \\
\text { intervention by a } \\
\text { third party }\end{array}$} & \multirow{6}{*}{$\begin{array}{l}\text { Integrative suicide prevention } \\
\text { program established in } 2002 \\
\text { which included telephone } \\
\text { hotlines, gatekeeper training and } \\
\text { suicide patrols. }\end{array}$} & $\begin{array}{l}\text { Before-and-after analysis } \\
\text { comparing number of }\end{array}$ & \multirow{3}{*}{$\begin{array}{l}\text { - Visitor completed suicides } \\
\text { dropped from } 37 \text { ( } 8.7 \text { per year) in } \\
\text { pre-intervention period to } 6(2.0 \\
\text { per year) in post-intervention } \\
\text { period. }\end{array}$} \\
\hline & & & & & suicides in two periods: & \\
\hline & & & & & . 1 Jan 1998 - 31 Mar 2002 & \\
\hline & & & & & $\begin{array}{l}\text { ( } 4.25 \text { year pre-intervention } \\
\text { period); and }\end{array}$ & \multirow{2}{*}{$\begin{array}{l}\text { - Visitor attempted suicides } \\
\text { remained relatively stable ( } 27 \text { ( } 6.4 \\
\text { per year) in pre-intervention } \\
\text { period; } 24 \text { ( } 6.9 \text { per year) in post- } \\
\text { intervention period). }\end{array}$} \\
\hline & & & & & $\begin{array}{l}\cdot 1 \text { Oct } 2002-31 \text { Mar } 2006 \\
\text { (3.50 year post-intervention } \\
\text { period). }\end{array}$ & \\
\hline & & & & & $\begin{array}{l}\text { Incorporated quasi- } \\
\text { experimental design element } \\
\text { which considered numbers of } \\
\text { completed and attempted } \\
\text { suicides in same periods on } \\
\text { two islands with similar } \\
\text { demographic profiles. }\end{array}$ & $\begin{array}{l}\text { - No comparable change in visitor } \\
\text { suicides on comparison islands } \\
\text { over study period. }\end{array}$ \\
\hline
\end{tabular}


question were associated with any commensurate increases in suicide at alternative sites in the given city. Of these, seven demonstrated that the number of suicides from other sites remained the same or decreased for the total population [23,24,27-29], or for males (who account for the majority of suicides by highly lethal methods, such as jumping from a height) $[17,18]$. However, Sinyor and Levitt [30] found no reduction in the overall numbers of suicides by jumping in Toronto during their respective study periods, suggesting that some substitution may have occurred.

Pelletier [28] and O'Carroll and Silverman [27] explored the substitution phenomenon further, and considered whether the observed reductions in suicides at the means-restricted sites equated to decreases in rates of suicide by any method (that is, not just jumping) in Augusta and Washington DC, respectively. Both of these studies identified small decreases in overall suicide rates following the means-restriction interventions.

\section{Encouraging help-seeking}

Three studies have examined the effectiveness of installing signs and telephones at specific hotspots as a way of encouraging suicidal individuals to seek help [21,25,33]. King and Frost [21] evaluated an intervention that involved the placement of signs providing contact details for the Samaritans placed in car parks in the New Forest in Hampshire (United Kingdom). Lester [25] evaluated crisis emergency telephones on the Sunshine Skyway Bridge in St Petersburg, Florida (United States) which were installed at the same time as the introduction of a police presence on the bridge (see below). Wong et al. [33] evaluated an integrated community-based program of initiatives designed to reduce suicides by visitors to Cheung Chau (Hong Kong), an island where a number of people had taken their own lives by charcoal burning in rented holiday flats. This included, among other things, the introduction of a 24-hour telephone hotline service to support people in emotional distress, and the provision of hotline numbers in all holiday flats.

All three studies showed reductions in suicides at the specific sites following the introduction of the intervention [21,25,33]. King and Frost [21] and Wong et al. [33] examined patterns of suicide at comparison sites (that is, at car parks with no signs in the New Forest, and at other Hong Kong islands, respectively) and found no change over the relevant observation period. King and Frost [21] also explored the impact of the reduction at the intervention sites on the overall number of suicides in the district and found that this decreased, suggesting that substitution had not occurred.
Increasing the likelihood of intervention by a third party

Three studies have explored the extent to which increasing the likelihood of intervention by a third party at hotspots can reduce suicide at these sites [17,18,25,33]. Two of these studies - by Lester [25] and Wong et al. [33] - have already been mentioned. They considered the impact of a range of activities on suicides from the Skyway Bridge and on Cheung Chau Island, respectively. This included a police presence on the former, and gatekeeper training and suicide patrols on the latter. Both studies reported positive findings in terms of reductions in numbers of suicides $[25,33]$.

The third study, by Bennewith and colleagues $[17,18]$, was also mentioned earlier. These authors examined an intervention that primarily involved the installation of barriers on the Clifton Suspension Bridge, but also included other components, namely an expansion of the role of bridge staff to include monitoring of incidents, and the installation of CCTV cameras. As noted, the intervention was associated with a reduction in suicides. The number of incidents remained stable, but bridge staff were more likely to be involved in incidents.

\section{Providing guidance on responsible media reporting of suicide}

A single study has considered whether providing guidance on responsible reporting of suicide at a hotspot can lead to reductions in suicide at that site, although the authors have strengthened the evidence by adding further data and conducting a follow-up analysis some years after they did the original work [19,20,26,32]. Etzersdorfer and Sonneck [19,20], Sonneck et al. [32] and Niederkrotenthaler and Sonneck [26] found that completed and attempted suicide on the Vienna underground railway system (Austria) rose significantly in the latter part of the pre-intervention period (when sensationalist reporting of suicide was common). They then observed that, following the introduction of guidelines on responsible reporting, suicidal acts dropped dramatically to a level that has been sustained since $[19,20,26,32]$. There was some evidence that this contributed to an overall reduction in the national suicide rate over time $[19,20,26,32]$.

\section{Discussion}

\section{Interpreting the findings}

Our review represents a consolidation of current knowledge about preventing suicides at hotspots, and an identification of gaps in that knowledge. Our starting point was the research question, 'What interventions are available to reduce suicides at hotspots, and are they effective?' The answer to the first part of this question is relatively straightforward. Four main approaches have been used at suicide hotspots: (a) restricting access to 
means (through installation of physical barriers); (b) encouraging help-seeking (by placement of signs and telephones); (c) increasing the likelihood of intervention by a third party (through surveillance and staff training); and (d) encouraging responsible media reporting of suicide (through guidelines for media professionals).

The answer to the second part of the question is more complex. The strongest evidence for effectiveness comes from studies that have looked at restricting access to means through the installation of barriers at jumping sites and on railway networks. This body of evidence consistently suggests that these measures are associated with a reduction in suicides at these sites because they limit access or make it difficult to perform suicidal acts. In the main, the evidence also suggests that restricting access to means at one site does not drive suicidal individuals to seek alternative locations, thereby shifting the problem elsewhere. There are also indications that reducing suicides by a particular method does not lead to substitution of different methods; instead it may have a positive impact on the overall suicide rate. The apparent effectiveness of installing barriers at suicide hotspots is consistent with the broader literature on restricting access to means as a population-level suicide prevention strategy. Reviews by Mann et al. [34] and Beautrais et al. [35] suggest that this is one of very few approaches for which there is strong evidence of effectiveness. The theory behind restricting access to means is that it may 'buy time' for the individual to reconsider his or her actions, particularly in situations where these actions are associated with impulsivity or ambivalence [36-38].

Beyond this, the evidence is weaker. The evidence for the effectiveness of interventions designed to encourage suicidal people to seek help (for example, crisis telephone lines) and interventions designed to increase the likelihood of intervention by a third party (for example, suicide patrols and CCTV) is limited. Relatively few studies have looked at their impact. Those which have done have tended to examine these strategies in the context of broader suicide prevention programs at given hotspots, and this has made their independent influence difficult to evaluate. It is fair to say, however, that they show sufficient promise regarding reducing suicides at hotspots to be worthy of further testing. Different models (for example, crisis telephone lines which link directly to mental health services [39]) may be worth exploring.

The provision of guidance on how to report suicides at hotspots has also been subject to limited testing. Only one study has evaluated this strategy specifically. Although this study was well-designed and covered a lengthy observation period, it was restricted to a single setting in a single country. The study suggested that supporting journalists and editors in responsible re- porting led to a decrease in suicidal acts on the rail network in question, and that this translated into a genuine overall reduction in suicides nationally. This is consistent with the literature on responsible reporting of suicide more generally (not just in the context of suicide hotspots), which suggests that guidelines can be effective in modifying the behaviour of media professionals and that this, in turn, can minimise imitation suicides [40-42].

\section{Future directions}

Further research in this area is clearly warranted, and good quality evaluations of the latter three types of interventions are particularly necessary. These evaluations should adopt the strongest designs possible in the context of implementing interventions at hotspots. Recognising that these are not likely to be randomised controlled trials, suicide prevention researchers should draw on other areas of public health which have grappled with the issue of what constitutes sufficiently good evidence of effectiveness $[43,44]$, and on the broader evaluation literature which stresses the importance of underpinning evaluations with sound program theory [45]. Triangulation of data from multiple sources is desirable, and might include both quantitative and qualitative data collection approaches. For example, ecological data (on pre- and post-intervention suicides from the site) could be combined with individual-level data (on the decision-making processes of those who sought help as a result of the intervention) where this is practically and ethically possible. Selecting comparison sites is also advantageous if this is feasible, particularly if the intervention can be rolled out across sites in a staggered fashion [46]. Likewise, examining the dose-response effect of gradually introducing the different components of a multi-faceted intervention may help to tease out the extent to which each individual component is effective. A consideration of cost-effectiveness is also important.

The above approaches to the reduction of suicides at known hotspots have been deemed to constitute current best practice, and have been advocated as part of a suite of potential measures in guidelines developed in England in 2006 (and translated into Japanese in 2007) [13], Scotland in 2012 [47] and Australia in 2012 [48]. This is appropriate under the circumstances; the need to strengthen the evidence base regarding interventions at hotspots should not prevent us from taking action in the immediate term, and the interventions considered in this review certainly show some promise. However, there is an onus on those who are responsible for funding and implementing these interventions to monitor them carefully to ensure that they are achieving their potential as effective suicide prevention strategies and are not having unintended consequences. Partnering with suicide prevention researchers with expertise in evaluation may be one way to do this. 


\section{Limitations of the review}

The current review has several limitations which must be acknowledged. We adopted as comprehensive a search strategy as we could, but resource constraints meant that we only had the capacity to search one database, we did not look for grey literature or conference abstracts, and we did not contact any authors for additional information. We did search two other databases (PsycINFO and Scopus) for a subsequent meta-analysis of studies on means restriction at hotspots and we found no additional papers [49]. Nonetheless, it is possible that some papers may have been missed. Publication biases may have operated, such that positive findings about particular interventions were more likely to have appeared in print than negative ones. It is also worth noting, however, that there would be instances where interventions have been implemented, with an effect, and not reported. This is particularly likely to be the case with barriers on bridges, which are not uncommon and may lead to reductions in suicides, but may not be reported in the scientific literature.

It was not always possible to determine the exact nature of the intervention. This was not so much a limitation of the review per se, but rather a limitation of the original studies. This limitation may have been a particular problem for the studies of restricting access to means, which tended to be reported as evaluations of a stand-alone intervention (the installation of barriers). Of these nine studies, only the one by Bennewith and colleagues $[17,18]$ provided detail of additional activities that were put in place alongside the barriers on the Clifton Suspension Bridge. A commentary on the study by Sinyor and Levitt [30] by Sakinofsky [50] indicated that the barriers at the Bloor Street Viaduct were complemented by a telephone crisis service, but this was not evident from the original paper. This may not have been an isolated case. The upshot of this is that impacts may have been attributed to a single intervention that in reality were at least in part due to other activities that ran alongside it.

These limitations were compounded by more basic difficulties of definition. Although we have provided a definition of the term 'hotspot', in practice this may have been applied fairly loosely across studies, with the result that different authors would use different thresholds to deem a site a hotspot. Similarly, the term 'intervention' is not universally understood. Some of the activities classified as interventions were in fact opportunistic activities (e.g., road closures), other interventions within the same group undoubtedly varied in scope and scale, and still others, as noted above, were delivered as part of a suite. Finally, the term 'effectiveness' must be interpreted in the light of the evidence available, with due acknowledgement being given to the study design issues mentioned above.

\section{Conclusions}

Notwithstanding the above limitations, we believe that our review demonstrates that there is consistent and relatively strong evidence that reducing access to means through the installation of barriers can be effective in averting suicides at hotspots and does not lead to substitution effects. The evidence is weaker for the other approaches that have been used, namely encouraging help-seeking, increasing the likelihood of intervention by a third party, and providing guidance on responsible media reporting of suicide, although they all show promise. This picture is consistent with the broader literature on suicide prevention, which suggests that there is good evidence that restricting access to means can work and that the majority of other interventions require further testing. Our review adds to this literature by focusing on the specific suite of interventions that have been used at suicide hotspots.

There is often community resistance to restricting access to means, despite this being the approach for which there is the greatest evidence of impact. Policy-makers and planners should be encouraged to recognize the demonstrated benefits of this approach, because they will often be faced with arguments of aesthetics and up-front costs which mean that they are likely to preferentially choose the other approaches. The other approaches may be useful too, but they clearly require further testing. More welldesigned intervention studies are needed to strengthen this evidence base.

\section{Competing interests}

The authors have no competing interests to declare.

\section{Authors' contributions}

JP, GRC, CO and JR were responsible for the original conceptualisation and design of the review, and $A L, M W$ and YTDC helped to refine its parameters. GRC conducted the literature search and retrieved all potential articles. GRC, $A L$ and JR screened abstracts and full text articles to arrive at the final pool. GRC and AN prepared early drafts of the paper, and all authors commented on and refined these drafts. All authors read and approved the final manuscript.

\section{Acknowledgements}

This review was funded by the Australian Government Department of Health and Ageing. CO was supported during the writing of this paper by the UK National Institute for Health Research Collaboration for Leadership in Applied Health Research and Care for the Southwest Peninsula.

\section{Author details}

'Orygen Youth Health Research Centre, Centre for Youth Mental Health, University of Melbourne, Melbourne, Australia. ${ }^{2}$ University of Exeter Medical School, Exeter, UK. ${ }^{3}$ Centre for Health Policy, Programs and Economics, Melbourne School of Population and Global Health, University of Melbourne, Melbourne, Australia.

Received: 1 November 2012 Accepted: 27 February 2013

Published: 9 March 2013

\section{References}

1. Beautrais AL: Suicide by jumping: A review of research and prevention strategies. Crisis 2007, 28(Suppl. 1):58-63. 
2. Owens C, Lloyd-Tomlins S, Emmens T, Aitken P: Suicides in public places: Findings from one English county. Eur J Public Health 2009, 19(6):580-582.

3. Blaustein M, Fleming A: Suicide from the Golden Gate Bridge. Am J Psychiatry 2009, 166(10):1111-1116.

4. Glasgow G: Do local landmark bridges increase the suicide rate? An alternative test of the likely effect of means restriction at suicidejumping sites. Soc Sci Med 2011, 72(6):884-889.

5. Cantor CH, Hill MA: Suicide from river bridges. Aust N Z J Psychiat 1990 24(3):377-380

6. Kerkhof A: Railway suicide: Who is responsible? Crisis 2003, 24(2):47-48.

7. De Leo D, Krysinska K: Suicidal behaviour by train collision in Queensland, 1990-2004. Aust NZ J Psychiat 2010, 42(9):772-779.

8. Caldwell T, Jorm A, Dear K: Suicide and mental health in rural, remote and metropolitan areas in Australia. Med J Australia 2004,

181(7 Suppl):s10-s14.

9. Elnour A, Harrison J: Lethality of suicide methods. Inj Prev 2007, 14:39-45.

10. Tranah T, Farmer R: Psychological reactions of drivers to railway suicide. Soc Sci Med 1994, 38(3):459-469.

11. Yum B, Roh J, Ryu J, Won J, Kim C, Lee J, Kim K: Symptoms of PTSD according to individual and work environment characteristics of Korean railroad drivers with experience of person-under-train accidents. J Psychosom Res 2006, 61(5):691-697.

12. Hamilton S, Metcalfe C, Gunnell D: Media reporting and suicide: A timeseries study of suicide from Clifton Suspension Bridge, UK, 1974-2007. J Public Health 2011, 33(4):511-517.

13. National Institute for Mental Health in England: Guidance on Action to be taken at Suicide Hotspots. London: National Institute for Mental Health in England; 2006

14. Moher D, Liberati A, Tetzlaff J, Altman D: Preferred Reporting Items for Systematic Reviews and Meta-Analyses: The PRISMA Statement. PLoS Med 2009, 6(6):e1000097.

15. Beautrais AL: Effectiveness of barriers at suicide jumping sites: $A$ case study. Aust NZ J Psychiat 2001, 35(5):557-562.

16. Beautrais AL, Gibb SJ, Fergusson DM, Horwood LJ, Larkin GL: Removing bridge barriers stimulates suicides: An unfortunate natural experiment. Aust NZ J Psychiat 2009, 43(6):495-497.

17. Bennewith O, Nowers M, Gunnell D: Effect of barriers on the Clifton suspension bridge, England, on local patterns of suicide: Implications for prevention. Br J Psychiatry 2007, 190:266-267.

18. Bennewith O, Nowers M, Gunnell D: Suicidal behaviour and suicide from the Clifton Suspension Bridge, Bristol and surrounding area in the UK: 1994-2003. Eur J Public Health 2011, 21(2):204-208.

19. Etzersdorfer E, Sonneck G: Newspaper reports and suicide. N Engl J Med 1992, 327:502-503

20. Etzersdorfer E, Sonneck G: Preventing suicide by influencing mass-media reporting: The Viennese experience, 1980-1996. Arch Suicide Res 1998, 4:67-74.

21. King E, Frost N: The New Forest Suicide Prevention Initiative (NFSPI). Crisis 2005, 26(1):25-33.

22. Isaac M, Bennett J: Prevention of suicide by jumping: The impact of restriction of access at Beachy Head, Sussex during the foot and mouth crisis 2001. Public Health Med 2005, 6(1):19-22.

23. Law CK, Yip PSF, Chan WSC, Fu K-W, Wong PWC, Law YW: Evaluating the effectiveness of barrier installation for preventing railway suicides in Hong Kong. J Affect Disorders 2009, 114(1-3):254-262.

24. Lester D: Suicide from bridges in Washington, DC. Percept Motor Skills 1993, 77(2):534

25. Lester D: Suicide by jumping from bridges. Percept Motor Skills 2005, 100(3 (Pt 1)):628

26. Niederkrotenthaler T, Sonneck G: Assessing the impact of media guidelines for reporting on suicides in Austria: Interrupted time series analysis. Aust N Z J Psychiatry 2007, 41(5):419-428.

27. O'Carroll P, Silverman M: Community suicide prevention: The effectiveness of bridge barriers. Suicide Life Threat 1994, 24(1):89-91. discussion 91-89.

28. Pelletier AR: Preventing suicide by jumping: The effect of a bridge safety fence. Inj Prev 2007, 13(1):57-59.

29. Reisch T, Michel K: Securing a suicide hot spot: Effects of a safety net at the Bern Muenster Terrace. Suicide Life Threat 2005, 35(4):460-467.

30. Sinyor M, Levitt AJ: Effect of a barrier at Bloor Street Viaduct on suicide rates in Toronto: natural experiment. BMJ 2010, 341:c2884.
31. Skegg $K$, Herbison P: Effect of restricting access to a suicide jumping site. Aust N Z J Psychiatry 2009, 43(6):498-502.

32. Sonneck G, Etzersdorfer E, Nagel-Kuess S: Imitative suicide on the Viennese subway. Soc Sci Med 1994, 38(3):453-457.

33. Wong PWC, Liu PMY, Chan WSC, Law YW, Law SCK, Fu K-W, Li HSH, Tso MK, Beautrais AL, Yip PSF: An integrative suicide prevention program for visitor charcoal burning suicide and suicide pact. Suicide Life Threat Behav 2009, 39(1):82-90.

34. Mann JJ, Apter A, Bertolote J, Beautrais A, Currier D, Haas A, Hegerl U, Lonnqvist J, Malone K, Marusic A, et al: Suicide prevention strategies: A systematic review. J Am Med Assoc 2005, 294(16):2064-2074.

35. Beautrais A, Fergusson D, Coggan C, Collings C, Doughty C, Ellis P, Hatcher S, Horwood J, Merry S, Mulder R, et al: Effective strategies for suicide prevention in New Zealand: A review of the evidence. NZ Med J 2007, 120(1251):U2459.

36. Gunnell D, Nowers M: Suicide by jumping. Acta Psychiatr Scand 1997, 96(1):1-6.

37. Hawton K: Restricting access to methods of suicide: Rationale and evaluation of this approach to suicide prevention. Crisis 2007, 28(Suppl. 1):4-9.

38. Yip $P$, Caine E, Yousuf S, Chang S-S, Wu K, Chen Y-Y: Means restriction for suicide prevention. Lancet 2012, 379:2393-2399.

39. Glatt K, Sherwood D, Amisson T: Telephone help lines at a suicide site. Hosp Community Psych 1986, 37(2):178-180.

40. Michel K, Frey C, Wyss K, Valach L: An exercise in improving suicide reporting in print media. Crisis 2000, 21:71-79.

41. Michel K, Maillart A, Reisch T: Monitoring of suicide reporting in print media 10 years after the publication of media guidelines: Did you expect anything else? In International Association for Suicide Prevention XXIV World Congress - Preventing Suicide Across the Lifespan. Killarney, Ireland: Dreams and Realities; 2007.

42. Pirkis J, Dare A, Blood RW, Rankin B, Williamson M, Burgess P, Jolley D: Changes in media reporting of suicide in Australia between 2000/01 and 2006/07. Crisis 2009, 30(1):25-33.

43. Victora C, Habicht J-P, Bryce J: Evidence-based public health: Moving beyond randomized trials. Public Health Matters 2004, 94(3):400-405.

44. Sanson-Fisher R, Bonevski B, Green L, D'Este C: Limitations of the randomized controlled trial in evaluating population-based health interventions. Am J Preventive Med 2007, 33(2):155-161.

45. Brousselle A, Champagne F: Program theory evaluation: Logic analysis. Eval Program Plann 2011, 34(1):69-78.

46. Brown C, Lilford R: The stepped wedge trial design: A systematic review. BMC Med Res Methodol 2006, 8(6):54

47. NHS Health Scotland: Guidance on Action to be Reduce Suicides at Locations of Concern. Edinburgh: NHS Scotland; 2012.

48. Lockley A, Williamson M, Robinson J, Cox G, Cheung Y-T, Grant L, Pirkis J: Preventing Suicide at Suicide Hotspots. Canberra: Australian Government Department of Health and Ageing; 2012.

49. Pirkis J, Spittal M, Cox G, Robinson J, Cheung Y-T, Studdert D: The effectiveness of structural interventions at suicide hotspots: A metaanalysis. Int J Epidemiol. In press.

50. Sakinofsky I: Barriers to suicide. Strategies at Bloor Viaduct. BMJ 2010, 341:c4447.

doi:10.1186/1471-2458-13-214

Cite this article as: Cox et al:: Interventions to reduce suicides at suicide hotspots: a systematic review. BMC Public Health 2013 13:214.

\section{Submit your next manuscript to BioMed Central and take full advantage of:}

- Convenient online submission

- Thorough peer review

- No space constraints or color figure charges

- Immediate publication on acceptance

- Inclusion in PubMed, CAS, Scopus and Google Scholar

- Research which is freely available for redistribution 